\title{
CLINICO PATHOLOGICAL STUDY OF CARCINOMA BREAST: A PROSPECTIVE STUDY
}

\author{
K. C. Madhu Shankar'1, T. R. Hari Prasad², S. T. Prahlad ${ }^{3}$
}

${ }^{1}$ Assistant Professor, Department of General Surgery, Rajarajeswari Medical College.

${ }^{2}$ Associate Professor, Department of General Surgery, Rajarajeswari Medical College.

${ }^{3}$ Assistant Professor, Department of General Surgery, Rajarajeswari Medical College.

\section{ABSTRACT}

\section{BACKGROUND}

Breast cancer is the most frequently diagnosed cancer in women and the second most cause of death in cancer. Over the past several decades there has been increase in incidence of the disease. Analysis of the incidence, clinical presentations, various risk factors, accuracy of FNAC and frozen section, incidence of various pathological types, stage at presentation and ER, PR, HER-2/neu status.

\section{METHODS}

In this prospective study, 51 consecutive patients who were diagnosed to have carcinoma breast admitted between April 2013 to April 2014 in the Department of Surgery, Rajarajeshwari Hospital, Bangalore, were included in the study. A detailed clinical history was elicited from all patients at the time of admission. All patients who had triple assessment evidence of malignancy were worked up for surgery with necessary investigations. Written consent was obtained from each patient for surgery. After data collection, it was checked, verified, edited manually for consistency to reduce error. Descriptive and graphical methods were used in analysing the data. The important variables were considered and analysed to fulfil the objective of the study.

\section{RESULTS}

In our study, the incidence of carcinoma breast is 5.6 per $1000,32 \%$ of them were between $41-50$ year age group, $63.3 \%$ had early menarche, $14.3 \%$ were nulliparous. Nearly $84.3 \%$ of them presented with lump of which $54 \%$ left sided involving upper outer quadrant $54.9 \%$. Most cases belong to stage II and stage III at the time of presentation. FNAC was done in all cases with accuracy rate of $82.4 \%$, followed by frozen section which showed about $71.4 \%$ of accuracy for those false negative cases.

\section{CONCLUSION}

Various risk factors in relation to breast carcinoma have been proved. As most of the cases presented late in our series because of lack of awareness, proper awareness and early screening by breast self-examination and mammogram should be emphasized. FNAC proved to be a simple and reliable procedure with good accuracy rate.

\section{KEYWORDS}

Carcinoma Breast, FNAC, Risk factors, Histopathology.

HOW TO CITE THIS ARTICLE: Shankar KCM, Prasad TRH, Prahlad ST. "Clinico pathological study of carcinoma breast: a prospective study." Journal of Evolution of Medical and Dental Sciences 2015; Vol. 4, Issue 105, December 31; Page: 17058-17061,

DOI: $10.14260 /$ jemds/2015/2584

\section{INTRODUCTION}

Breast cancer is the most common site specific cancer in women and is the leading cause of death from cancer for women aged 20-59 yrs. ${ }^{1}$ Peak incidence is in the 5th and 6th decades, but in India the disease is seen a decade earlier-the mean age of occurrence is 42 , as compared to 53 in white women. Breast cancer causes 5,19,000 deaths in a year worldwide, about 9,00,000 women are diagnosed each year. ${ }^{2}$ 1 in 8 women have lifetime risk of developing breast cancer. ${ }^{2}$ In Indian women breast cancer is the most common cause of cancer death. It is reported that breast cancer is proportionately on the rise in a few metropolitan areas of India.

Financial or Other, Competing Interest: None.

Submission 03-12-2015, Peer Review 04-12-2015,

Acceptance 26-12-2015, Published 31-12-2015.

Corresponding Author:

KC Madhu Shankar,

Assistant Professor,

Department of General Surgery,

202, Kambipura, Mysore Road,

Bangalore-560074.

E-mail:kcmadhushankar@gmail.com

DOI:10.14260/jemds/2015/2584
This appears to be related to late marriage, birth of the first child at a later age, fewer children and short period of breast feeding, which are increasingly common practice among the educated urban women. ${ }^{3}$ The natural history of breast cancer is characterized by long duration and heterogeneity among patients.

\section{AIM OF THE STUDY}

- To evaluate the clinical presentation and pathological features of breast cancer with respect to age and stage of the disease.

- To correlate the clinical findings with FNAC reports and postoperative histopathology reports.

\section{MATERIALS AND METHODS \\ Inclusion Criteria}

All patients who were diagnosed to have carcinoma breast.

\section{METHODOLOGY}

A detailed clinical history was elicited from all patients at the time of admission. All patients who were diagnosed with carcinoma breast based on triple assessment were worked up 
for surgery with necessary investigations. Written consent was obtained from each patient for surgery.

\section{ETHICS}

The procedures followed were in accordance with the ethical standards of the responsible committee on human experimentation (Institutional or Regional) and with the Helsinki Declaration of 1975 that was revised in 2000. (http://www.wma.net/e/policy/17-c_e.html.)

\section{DATA ANALYSIS}

After collection, the data was checked, verified, edited manually for consistency to reduce error. Descriptive and graphical methods were used in analysing the data. Chi square test and $p$ value were considered for student $t$ test and analysed to fulfil the objective of the study.

\section{RESULTS}

The following data were obtained from the present study of 51 cases studied in Department of Surgery, Rajarajeswari Medical College and Hospital, Bangalore, from April 2013 to April 2014.

\begin{tabular}{|c|c|c|}
\hline Age in Years & No. of Patients & Percentage \\
\hline$<20$ & 0 & 0 \\
\hline $21-30$ & 1 & 2 \\
\hline $31-40$ & 7 & 14 \\
\hline $41-50$ & 16 & 32 \\
\hline $51-60$ & 12 & 24 \\
\hline $61-70$ & 8 & 16 \\
\hline$>70$ & 6 & 12 \\
\hline Total & $\mathbf{5 0}$ & $\mathbf{1 0 0}$ \\
\hline \multicolumn{3}{|c|}{ Table 1: Age Distribution } \\
\hline
\end{tabular}

In our study, most of the patient's cases belonged to 4150 yrs age group, of which male constitute $2 \% ; 57.2 \%$ were post-menopausal state; $14.3 \%$ were nulliparous, who were not breast fed. In our study only $2 \%$ had family history; $84.3 \%$ of patients presented with breast lump upper outer quadrant (54.9\%) and $92.15 \%$ presented with $>2 \mathrm{cms}$ tumour. When age is stratified for 20 years, there is significant increase in incidence in 41-60 age group as $\mathrm{p}<0.05$.

\begin{tabular}{|c|c|c|}
\hline Stage & No. of Cases & Percentage \\
\hline 0 & 0 & 0 \\
\hline I & 3 & 5.9 \\
\hline IIA & 15 & 29.4 \\
\hline IIB & 9 & 17.6 \\
\hline IIIA & 8 & 15.7 \\
\hline IIIB & 14 & 27.5 \\
\hline IIIC & 0 & 0 \\
\hline IV & 2 & 3.9 \\
\hline Total & $\mathbf{5 1}$ & $\mathbf{1 0 0}$ \\
\hline \multicolumn{3}{|c|}{ Table 2: Clinical TNM Staging } \\
\hline
\end{tabular}

$\mathrm{N}=51$. No single stage was significant with $\mathrm{p}>0.05$.

\begin{tabular}{|c|c|c|}
\hline FNAC & No. of Cases & Percentage \\
\hline Malignant & 42 & 82.4 \\
\hline Suspicious of carcinoma & 4 & 7.8 \\
\hline Benign & 5 & 9.8 \\
\hline Total & $\mathbf{5 1}$ & $\mathbf{1 0 0}$ \\
\hline \multicolumn{2}{|c|}{ Table 3: FNAC Procedure } \\
\hline
\end{tabular}

\begin{tabular}{|c|c|c|c|c|c|}
\hline \multicolumn{2}{|l|}{ FNAC } & \multicolumn{2}{|c|}{$\begin{array}{l}\text { Frozen } \\
\text { Section }\end{array}$} & $\begin{array}{c}\text { Exci } \\
\text { sion } \\
\text { biop } \\
\text { sy }\end{array}$ & $\begin{array}{c}\text { Final } \\
\text { HPE } \\
\text { as } \\
\text { malign } \\
\text { ant } \\
\end{array}$ \\
\hline Malignant & 42 & \multicolumn{2}{|c|}{0} & 0 & 42 \\
\hline \multirow{3}{*}{$\begin{array}{c}\text { Suspicious } \\
\text { of } \\
\text { malignancy }\end{array}$} & \multirow{3}{*}{4} & \multicolumn{2}{|c|}{4} & \multirow{3}{*}{0} & \multirow{3}{*}{4} \\
\hline & & Malignant & Benign & & \\
\hline & & 3 & 1 & & \\
\hline \multirow{3}{*}{ Benign } & \multirow{3}{*}{5} & \multicolumn{2}{|c|}{3} & \multirow{3}{*}{2} & \multirow{3}{*}{5} \\
\hline & & Malignant & Benign & & \\
\hline & & 2 & 1 & & \\
\hline Total & 51 & \multicolumn{2}{|c|}{7} & 2 & 51 \\
\hline \multicolumn{6}{|c|}{$\begin{array}{l}\text { Table 4: Correlation of FNAC, Frozen section, } \\
\text { Excision biopsy and HPE }\end{array}$} \\
\hline
\end{tabular}

\begin{tabular}{|c|c|c|}
\hline Type of Tumour & $\begin{array}{c}\text { No. of } \\
\text { Cases }\end{array}$ & Percentage \\
\hline Invasive ductal carcinoma & 41 & 80.39 \\
\hline Medullary carcinoma & 4 & 7.84 \\
\hline Colloid carcinoma & 1 & 1.96 \\
\hline $\begin{array}{c}\text { Infiltrative lobular } \\
\text { carcinoma }\end{array}$ & 1 & 1.96 \\
\hline Secretory carcinoma & 1 & 1.96 \\
\hline Invasive papillary & 1 & 1.96 \\
\hline Comedocarcinoma & 1 & 1.96 \\
\hline Ductal carcinoma in-situ & 1 & 1.96 \\
\hline Paget's disease & 0 & 0 \\
\hline Cystosarcoma phylloid & 0 & 0 \\
\hline Others & 0 & 0 \\
\hline Total & $\mathbf{5 1}$ & $\mathbf{9 9 . 9 9}$ \\
\hline Table 5: Histopathology of Specimen \\
\hline
\end{tabular}

The incidence of invasive ductal carcinoma is significant with $\mathrm{p}<0.05$.

\begin{tabular}{|c|c|c|}
\hline Nodes & No. of Cases & Percentage \\
\hline No metastasis & 20 & 39.2 \\
\hline $1-4$ & 19 & 37.3 \\
\hline$>4$ & 12 & 23.5 \\
\hline Total & $\mathbf{5 1}$ & $\mathbf{1 0 0}$ \\
\hline \multicolumn{2}{|c|}{ Table 6: Histopathological Nodal Involvement } \\
\hline
\end{tabular}

No significant correlation of nodal status with $\mathrm{p}>0.05$.

\begin{tabular}{|c|c|c|c|c|c|c|}
\hline Receptor & ER & $\%$ & PR & $\%$ & $\begin{array}{l}\text { HER- } \\
2 / \text { neu }\end{array}$ & $\%$ \\
\hline Positive & 17 & 34 & 19 & 38 & 8 & 16 \\
\hline Negative & 33 & 66 & 31 & 62 & 42 & 84 \\
\hline Total & 50 & 100 & 50 & 100 & 50 & 100 \\
\hline
\end{tabular}

\begin{tabular}{|c|c|c|}
\hline Treatment & $\begin{array}{l}\text { No. of } \\
\text { Cases }\end{array}$ & $\%$ \\
\hline Surg + CT & 12 & 24 \\
\hline Surg + CT + RT & 16 & 32 \\
\hline Surg + CT + RT + HT & 10 & 20 \\
\hline Surg + CT + HT & 10 & 20 \\
\hline Neoadj CT + Surg + CT+RT & 2 & 2 \\
\hline Neoadj CT+Surg+CT+RT+HT & 1 & 2 \\
\hline Total & 51 & 100 \\
\hline \multicolumn{3}{|c|}{ Table 8: Treatment } \\
\hline
\end{tabular}




\section{DISCUSSION}

Present study was conducted to find out the incidence of breast carcinoma in our hospital with their clinical presentations, various risk factors, accuracy of FNAC and frozen section, incidence of various pathological types and nodal involvement, stage at presentation, ER, PR, HER-2/neu status.

The incidence of breast cancer in our hospital during the study period is 5.56 per 1000 patients. In our study the youngest patient is 27 years old and the oldest is 87 years. $32 \%$ of patients were between 41-50 years age group. In a study done by Saghir et al. 39.9\% were between 35 and 49 and 52\% were aged 50 years and above. 4

The peak incidence of carcinoma of the breast was observed by Smith et al. ${ }^{5}$ in 2002 in $4^{\text {th }}$ decade. The peak incidence reported by National Cancer Registry. ${ }^{6}$ was highest in $2^{\text {nd }}$ decade and Age distribution showed two peaks at 41-50 years and 51-60 years as per Binder Chopra et al. ${ }^{7}$ which was nearer to our study.

In our study $63.3 \%$ of patients had their menarche before 14 years, which supports the fact that early menarche is associated with longer exposure of breast tissue to estrogen stimulation, which is comparable to study done by Soon Young Lee, et al. ${ }^{8}$ which is $73.33 \%$

In our study $10.2 \%$ of patients had their first pregnancy before 20 years, which correlates well with Bernstein et al. ${ }^{9}$ which shows $12 \% .14 .3 \%$ of our patients were nulliparous as compared to $16.5 \%$ with Sara et al.10

Most breast cancers present with hard lump, which is about $84.3 \%$ cases in our series which is comparable to HJG Bloom, WW Richardson and E. J. Harries who noted lump in $83 \%$, which is followed by pain, ulcer and nipple discharge $5.9 \%$; $8 \%$ and $3.9 \%$ which is very close to Bloom HJG series $6 \%, 8 \%$ and $3 \%$ respectively.

Upper outer quadrant being more common of about $54.9 \%$ which is comparable to $53.3 \%$ in Darbre et al. series. ${ }^{11}$

Surveillance, Epidemiology and End Results (SEER) Program, 9 SEER Registries, National Cancer Institute shows. ${ }^{12}$ $80 \%$ of cases in stage I disease, which reflects early detection in Western population followed by $40 \%$ and $10 \%$ of stage II and stage III respectively, which is not comparable with our series which is $5.9 \%, 47 \%, 43.2 \%$ and $3.9 \%$ of stage I, II, II and IV respectively.

All patients in our series are subjected to FNAC in which $82.4 \%$ were diagnosed as malignant rest of $17.6 \%$ were diagnosed malignant after doing frozen section and excision biopsy.

The accuracy rate of FNAC in our series is $82.4 \%$, which is similar to $95 \%$ of Moschetta et al. ${ }^{13}$ series, but the false negative cases in our study are $9.8 \%$, which is significant as compared to the above series. Out of 7 cases 5 were diagnosed as malignant in frozen section which reflects $71.4 \%$ accuracy.

Invasive ductal carcinoma being most common histopathological variant, which constitute $80.39 \%$.

\section{CONCLUSION}

In our present study we can conclude that a significant incidence of breast cancer in our set up is highest between fourth and fifth decade of life. Age at menarche, age at first birth, breast feeding and parity as risk factors has been proved. Lump as a main presenting complaint with involvement of left breast upper outer quadrant also been justified.
But most of our patients present at stage II and stage III which reflects lack of awareness among our population. Early detection and prompt treatment can be achieved by proper health education, increased awareness, screening by regular physical examination and mammography of the people at risk.

Emphasis should be given for proper way of selfexamination of the breast and inform the physician promptly whenever abnormality is felt, as early detection and early treatment provides better results.

Even though FNAC has been established as a simple and effective method of diagnosing breast cancer, further evaluation is required to rule out carcinoma either by frozen section and excisional biopsy in false negative cases rather than leaving it alone in clinically suspicious cases.

\section{REFERENCES}

1. Charles Brunicardi F, Schwartz' Principles of Surgery, 2009, 10th edn, Chapter 17, The Breast, Pages 440-441.

2. Park K. "Textbook of Preventive and Social Medicine," 2009, 20th edn, Chapter 6, Epidemiology of Chronic Noncommunicable Diseases and Condition, Cancer, Page 338.

3. Dickson BR, Pestele RG, Lippman ME. Cancer of the breast In: Devita VT, Rosenberg SA, Eds. Cancers Principles and Practice of Oncology, 7th edn. Philadelphia, Lippincotts, Williams and Wilkins, 2001;1399-1477.

4. Nagi S, El Saghir1, Muhieddine Seoud2, et al. Effects of young age at presentation on survival in breast cancer BMC Cancer. 2006;6:194.

5. Smith A, Hall P, Marcello D. Emerging technologies in breast cancer detection. International agency for research on cancer hand book: University press; 2002.

6. Data were provided by the Office for National Statistics on request, July 2014. Similar data can be found here: http://www.ons.gov.uk/ons/rel/vsob1/cancerstatistics-registrations--england--series-mb1/index.html (link is external).

7. Brinder Chopra1, Vaneet Kaur1, Kamaljit Singh. Age shift: Breast cancer is occurring in younger age groupsIs it true?:CCIJ;2014;3(6):5265-529.

8. Lee SY, Kim MT, Kim SW, et al. Effect of lifetime lactation on breast cancer risk: A Korean women's cohort study. Int J Cancer 2003;105:390-393.

9. Bernstein L. Epidemiology of endocrine-related risk factors for breast cancer. Journal of Mammary Gland Biology and Neoplasia 2002;7(1):3-15.

10. Sara J Schonfeld, Ruth M Pfeiffer, James V Lacey Jr. Hormone-related risk factors and postmenopausal breast cancer among nulliparous versus parous women: An Aggregated Study: Oxford J 2010;173(5):509-517.

11. Darbre PD. Recorded quadrant incidence of female breast cancer in Great Britain suggests a disproportionate increase in upper outer quadrant of the breast. Anticancer Res. 2005 May-Jun;25(c):2543-50.

12. Howlader N, Noone AM, Krapcho M, et al., eds. SEER Cancer Statistics Review, 1975-2010. Bethesda, MD: National Cancer Institute; 2013.

http://seer.cancer.gov/csr/1975_2010/, based on November 2012 SEER. 


\section{Jemds.com}

Original Article

13. Moschetta M, Telegrafo M, Carluccio DA. Comparison between Fine Needle Aspiration Cytology (FNAC) and Core Needle Biopsy (CNB) in the diagnosis of breast lesions. G Chir. 2014 Jul-Aug;35(7-8):171-176. 